\title{
Abiotic conditions shape the relationship between indigenous and exotic species richness in a montane biodiversity hotspot
}

\author{
Manuel R. Popp $\mathbb{D} \cdot$ Jesse M. Kalwij $\mathbb{D}$
}

Received: 2 October 2020/ Accepted: 27 January 2021

(C) The Author(s) 2021, corrected publication 2021

\begin{abstract}
Montane ecosystems are more prone to invasions by exotic plant species than previously thought. Besides abiotic factors, such as climate and soil properties, plant-plant interactions within communities are likely to affect the performance of potential invaders in their exotic range. The biotic resistance hypothesis predicts that high indigenous species richness hampers plant invasions. The biotic acceptance hypothesis, on the other hand, predicts a positive relationship between indigenous and exotic species richness. We tested these two hypotheses using observational data along an elevational gradient in a southern African biodiversity hotspot. Species composition data of indigenous and exotic plants were recorded in 20 road verge plots along a gradient of
\end{abstract}

Communicated by Katinka Ruthrof.

Supplementary Information The online version of this article (doi:https://doi.org/10.1007/s11258-021-01116-6) contains supplementary material, which is available to authorized users.

M. R. Popp · J. M. Kalwij ( $\square)$

Institute of Geography and Geoecology, Karlsruhe Institute of Technology, Reinhard-Baumeister-Platz 1,

76131 Karlsruhe, Germany

e-mail: jessek@uj.ac.za

J. M. Kalwij

Centre for Ecological Genomics \& Wildlife Conservation, Department of Zoology, University of Johannesburg,

Auckland Park 2006, South Africa
1775-2775 m a.s.l. in the Drakensberg, South Africa. Plots were $2 \times 50 \mathrm{~m}$ in size and positioned at $50 \mathrm{~m}$ elevational intervals. We found a negative correlation between indigenous and exotic richness for locations with poorly developed mineral soils, suggesting biotic resistance through competitive interactions. A strong positive correlation for plots with very shallow soils at high elevations indicated a lack of biotic resistance and the possibility of facilitating interactions in harsher environments. These results suggest that biotic resistance is restricted to the lower and mid elevations while biotic acceptance prevails in presence of severe abiotic stress, potentially increasing the risk of plant invasions into montane biodiversity hotspots.

Keywords Alien invaders - Altitudinal gradient . Mountainous ecosystems $\cdot$ Native species $\cdot$ Sani pass

\section{Introduction}

Montane regions host a considerable proportion of terrestrial plant biodiversity (Barthlott et al. 2007). An important evolutionary factor behind this diversity is habitat isolation and fragmentation at high elevation, leading to speciation and regional diversification (Rahbek et al. 2019). At small spatial scales, variation in topography and exposure creates a multitude of microhabitats with different water and nutrient 
regimes, substrate types, and microclimatic niches, each favouring characteristic plant communities (Körner 2003). Across larger scales, the main driver of plant biodiversity is the steep elevational gradient, which generates a series of geophysical conditions, compressing life zones otherwise only found over many degrees of latitude within short spatial distances (Bowman and Damm 2002). Steep abiotic gradients also hold the potential for environmental stress, which is considered an important variable limiting species ranges (Alpert et al. 2000). For example, increasing elevation is associated with a decrease in atmospheric pressure and partial pressure of atmospheric gases (Körner 2003). This trend is accompanied by a reduction of atmospheric temperature and an increase of incoming solar radiation, as well as outgoing nighttime thermal radiation. The fraction of UV-B radiation also increases with elevation (Körner 2007). Additionally, the often poorly developed soil limits successful plant establishment at higher elevations (Körner 2003; Pauchard et al. 2009). Such barriers limit the risk that an introduced species becomes naturalized or even invasive (Petitpierre et al. 2016; Richardson et al. 2000). Therefore, the occurrence of plant invasions was thought to be rather unlikely in high elevation environments. More recently, however, there is increasing evidence that montane ecosystems are at risk of plant invasions (Alexander et al. 2016). This is partly due to intensifying human activities in montane regions (Haider et al. 2018; Kalwij et al. 2008; McDougall et al. 2018). In addition, global warming will attenuate the low temperature associated with montane ecosystems in the long term and potentially facilitate the establishment of exotic species (Pauchard et al. 2009; Petitpierre et al. 2016). Although plant invasions in montane areas are increasingly studied, it remains unclear which factors determine patterns of exotic species distribution and how indigenous species richness affects the establishment of exotic species along steep elevational gradients (Alexander et al. 2016; Pauchard et al. 2009).

In his 1958 book, C. S. Elton introduced the idea that communities were able to resist invasions through a combination of various biotic processes with varying degrees of success (Elton 1958). Based on observations of oceanic islands and crop monocultures, he presumed that simple communities were more prone to invasions than diverse ones (Levine and D'Antonio
1999). Elton's explanation on the impact of introduced species on resident communities became known as the biotic resistance hypothesis. The effect of indigenous species diversity can be explained through the diffuse competition model (MacArthur 1970), in which communities with high species richness have more potential niche overlap with new species and are therefore able to resist invasion. While functional diversity is associated with species richness (Petchey and Gaston 2002), most authors agree on an effect of species richness per se (Feng et al. 2019; Naeem et al. 2000). For example, as species richness increases the probability that the resident community harbours key species limiting the success of potential invaders (Levine and D'Antonio 1999). The presence of competitors is, therefore, considered to be a main contributor to biotic resistance (Levine et al. 2004).

While various controlled experiments support the biotic resistance hypothesis (Kennedy et al. 2002), contradictory field observations in montane communities suggest that resident diversity does not necessarily prevent plant invasions (Ackerman et al. 2017). For example, various studies found a positive relationship between indigenous and exotic species richness (McKinney 2002; Stohlgren et al. 2003). This led to the proposal of the biotic acceptance hypothesis (Stohlgren et al. 2006). According to this hypothesis, both indigenous and exotic species richness respond to resource availability and habitat heterogeneity. Introduced species may coexist despite the abundance of indigenous species. Diversity within the resident communities itself can even facilitate invasibility through increased small-scale environmental heterogeneity and the possibility of mutualism (Palmer and Maurer 1997). Consequently, a diverse community is not resistant to new arrivals but is, instead, more prone to invasions (Stohlgren et al. 2006). The harsh abiotic conditions at high elevations cause stress to exotic plants. Indigenous montane plant communities create their own suitable microenvironment to ameliorate physical stress, which is why the biotic acceptance hypothesis is expected to prevail at high elevations in particular (Pauchard et al. 2009; Simberloff and Von Holle 1999).

The biotic resistance and biotic acceptance hypotheses predict opposing effects of resident species richness on arriving exotics. The outcome of studies in favour of one hypothesis or the other can be affected by spatial extent and resolution (Stohlgren et al. 1999). 
At sites with a limited spatial extent, a negative relationship between indigenous and exotic species richness due to competition is common (Shea and Chesson 2002). A large spatial extent, on the other hand, is associated with a high environmental heterogeneity and, thus, increased niche opportunities and species diversity in general. Such is the case for comparisons at landscape and biome scales (Stohlgren et al. 1999). Here, a positive relationship between indigenous and exotic species richness will be found when variation in extrinsic factors are not taken into account (Shea and Chesson 2002). At a local scale, besides the relative importance of competition and facilitation, spatial variance in disturbance, or colonisation rates, and environmental heterogeneity affect the relationship between indigenous and exotic species richness (Fridley et al. 2007). In a montane area, a positive relationship is expected especially under the harsh conditions at high elevations (Callaway et al. 2002). Here, abiotic factors, such as climatic barriers limit the success of exotic species, which are often generalists and not particularly well adapted (Steyn et al. 2017). However, when the importance of competition is low and plant-plant interaction ameliorates abiotic stress, as is the case at high elevations, exotic plant species may profit from facilitation (Callaway et al. 2002; Choler et al. 2001). Moreover, once the number of exotic species increases, facilitation within the community could pave the way for even more potential invaders (Simberloff and Von Holle 1999). Thus, biotic resistance may be restricted to lower elevations, where crowding and competitive interactions override abiotic effects. At higher elevations, facilitation is more likely to prevail and biotic acceptance might explain the impact of indigenous species richness on the invasibility of the ecosystem (Callaway et al. 2002; Choler et al. 2001).

A suitable area to test the direction and extent to which indigenous species and abiotic drivers of montane ecosystems affect the distribution of exotics has a spatial extent that is large enough to provide a long elevational gradient and diversity in indigenous species richness. Mountain roads provide the required spatial extent and environmental gradients (Alexander et al. 2009). Anthropogenic disturbances and propagule pressure have an impact shaping invasion (Alexander et al. 2016; Lockwood et al. 2005). Differences in the density of human activities should be avoided, such as the occurrence of road intersections (McDougall et al. 2018), or trail crossings and resting places for hikers (Liedtke et al. 2020). Therefore, the spatial extent of the study area should also be small enough to keep such factors as constant as possible. Alternatively, those variables should be well documented and controlled for. Finally, there must be some pool of exotic species present. Such areas can be found in the Maloti-Drakensberg, South Africa. This mountain range covers steep elevational ranges and has an exceptionally species-rich indigenous flora (Carbutt 2019). At the same time, exotic species are increasing in richness and abundance (Carbutt 2012; Kalwij et al. 2015) This mountain range is sparsely populated and contains only few roads. One of which follows the steepest road gradient in southern Africa, covering an elevational range from about 1500 to more than $3000 \mathrm{~m}$ a.s.l. Here, spatio-temporal trends in exotic species are annually monitored since 2007 (Kalwij et al. 2008), so that introduction history and propagule pressure are known in detail. The primary underlying mechanism for this increase is the transportation of propagules into the area by anthropogenic means, rather than by gradual range expansion from the lowland (Kalwij et al. 2008, 2015). Here, we have the opportunity to gain a better understanding of the relationship between indigenous and exotic species in montane ecosystems.

In this study, we test if there is a relationship between indigenous and exotic species along an elevational gradient. We collected species composition data from road verge transects at $50 \mathrm{~m}$ elevational intervals within a range of $1775-2775 \mathrm{~m}$ a.s.l. along the steepest elevational gradient in southern Africa. Furthermore, we will examine which abiotic factors determine exotic species composition using a distance-based redundancy analysis (db-RDA). These results are then used to evaluate whether the biotic resistance hypothesis or the biotic acceptance hypothesis applies.

\section{Methods}

Study area

The study was set up along a 20-km section of the Sani Pass Road, covering an elevational range of 1750 to $2775 \mathrm{~m}$ a.s.1. through a largely pristine mountain 
valley with steep slopes and shallow, skeletal soils at the border between South Africa and Lesotho (Fig. 1). It is part of the Maloti-Drakensberg Park, a biodiversity hotspot within the grassland biome of South Africa (Carbutt 2019; Mucina and Rutherford 2006). The area receives about $860 \mathrm{~mm}$ of annual precipitation at lower elevations, down to $770 \mathrm{~mm}$ at the top, mainly falling during summer (October-March; Nel and Sumner 2008). Mean daily ground temperatures reach summer maxima of $19{ }^{\circ} \mathrm{C}$ and $14{ }^{\circ} \mathrm{C}$ and winter minima of $14{ }^{\circ} \mathrm{C}$ and $3{ }^{\circ} \mathrm{C}$ at the lower and higher end of the gradient, respectively. Mean daily air temperatures may fall well below zero at higher elevations, allowing for snowfall during the coldest months (Bishop et al. 2014; Nel and Sumner 2008).

The road verges were regularly disturbed by erosion and road maintenance activities while the road itself is frequented by approximately $10004 \times 4$ vehicles per month; this combination of disturbance factors continuously generates unoccupied habitats and facilitates the introduction of new species. Those may originate from both distant and nearby source populations, and can be introduced through vehicles and livestock movements along the road. At least 104 exotic plant species have been found in the study area (Kalwij et al. 2015).

\section{Data collection}

Plant species data were collected in January 2018. Rectangular plots of $2 \times 50 \mathrm{~m}$ were placed parallel and adjacent to the road surface. These dimensions were chosen to investigate processes at a local scale (Seipel et al. 2012). The lowest elevation plot was placed at $1775 \mathrm{~m}$ a.s.l. with subsequent plots at elevational distances of $50 \mathrm{~m}(N=20$ plots; 1825 and $1925 \mathrm{~m}$ a.s.l. were not recorded due to logistic constraints). In each plot, total indigenous and exotic cover as well as species-specific cover was estimated in categories of $<1 \%, 1-5 \%, 6-25 \%, 26-50 \%$, $51-75 \%, 76-95 \%$ and $96-100 \%$. These cover estimations follow the standardised method as proposed by the Mountain Invasion Research Network (MIREN; Kueffer et al. 2014).

Climate data were taken from the CIB data repository (Ferreira 2003-2015). This data repository contains soil temperature data measured along the Sani Pass over a 4-year period (2012-2015). Outliers and data gaps were eliminated through the use of

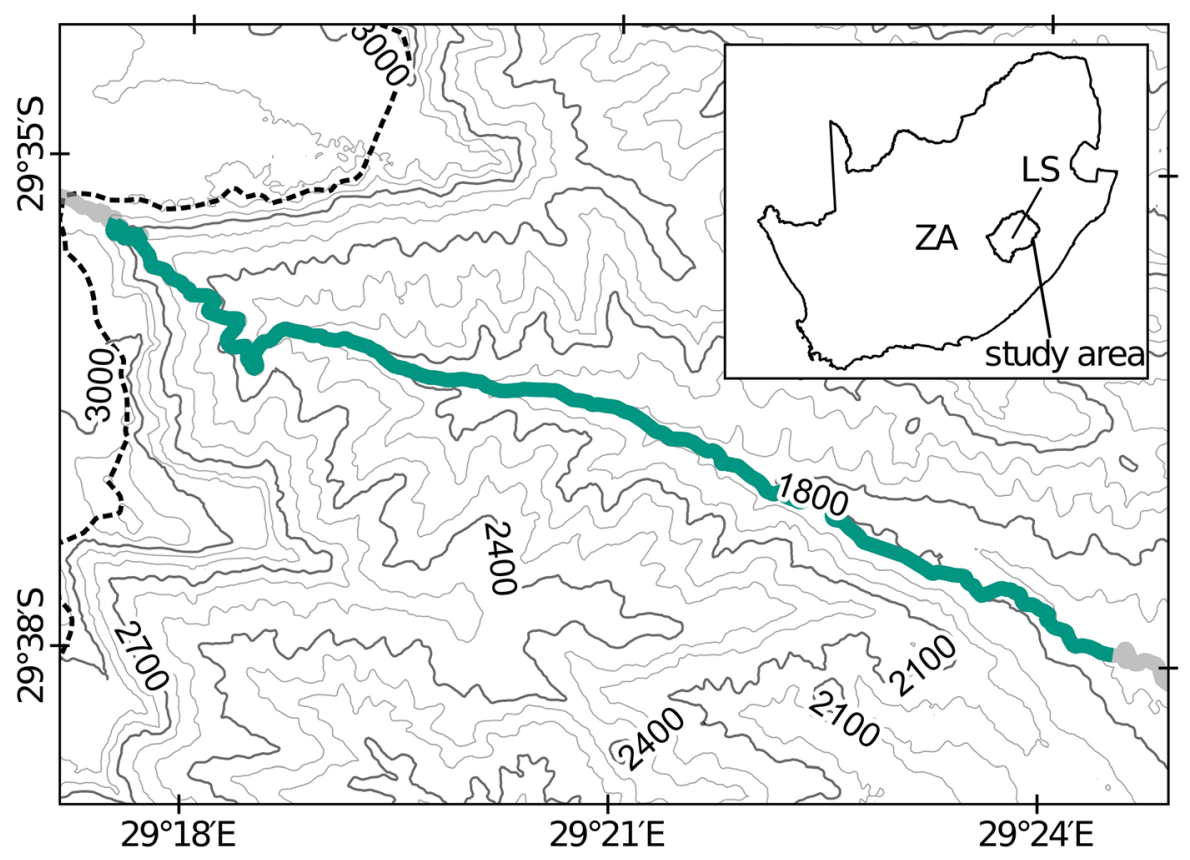

Fig. 1 Overview of the study area showing the section of the Sani Pass Road (thick line) along which transects were located. The inlet indicates the position of the study area at the border between South Africa (ZA) and Lesotho (LS). The border is indicated by a dotted line on the main map. Projection: UTM zone $35 \mathrm{~S}$ 
sinusoidal non-linear least squares regression models. Average daily and annual temperatures (mean annual temperature $T_{\text {mean }}$, mean temperature of the coldest/ warmest day $T_{\min } / T_{\max }$ ) were calculated from model parameters. Since the locations of temperature loggers and species sampling were only in close proximity to road verge plots, elevation-specific temperature measurements were estimated based on local polynomial regression models. For more details, see Supplementary Data (Appendix S1).

To determine the impact of soil properties, we extracted lithology, landform, and soil information from the SOTER soil and terrain database v 1.0. For South Africa, this database has an estimated spatial resolution of some 500-1000 m (Appendix S2; ISRIC 2013). The study area comprises three soil and landform types: (1) RGe/TM are eutric Regosolsweakly developed mineral soils on unconsolidated materials, but with a high base saturation - on steep mountainsides; (2) $\mathrm{RGd} / \mathrm{LV}$ are similar soils, although with a low base saturation and located at the valley floor; and (3) LPq/TE, lithic Leptosols, which are very shallow soils $(\leq 10 \mathrm{~cm})$ on continuous rock at high gradient escarpment zones. We analysed soil/landform information (hereafter referred to as soil type) as an ordinal scaled variable to account for varying suitability of the sampling locations as plant habitats. Lithic Leptosols are less habitable than dystric and eutric Regosols (Hazelton and Murphy 2016; IUSS Working Group WRB 2015). However, pedological surveying and assessment of the soils was beyond the scope of this study and, consequently, more detailed information on soil properties was not included.

Data analysis

Correlations between native and exotic species richness and abundance, temperature indices and elevation were determined through a preliminary calculation of the Pearson correlation coefficients and visual inspection.

The effect of biotic and abiotic variables (indigenous species richness, $T_{\text {min }}, T_{\text {mean }}, T_{\text {max }}$, elevation, soil type) on exotic species cover was tested using canonical analysis. Traditional redundancy analysis (RDA) preserves the Euclidean distance which is not appropriate for data sampled in highly diversified regions, i.e., long gradients (Legendre and Gallagher 2001). This is the case for our study area (first DCA ordination axis length $=3.8$ ). We therefore applied a distance-based approach (db-RDA) to preserve the square-root transformed Bray-Curtis distance, which is a modification of the Sørenson index applicable to species abundance data (Chao et al. 2005). The analysis was carried out following McArdle and Anderson (2001). First, a general test was applied to confirm that the overall model using all variables was significant. When proceeding with forward parameter selection, a significance threshold $p<0.05$ and adjusted coefficient of multiple determination $\left(R_{\mathrm{a}}^{2}\right)$ were employed as selection criteria (Blanchet et al. 2008). A backward elimination resulted in the same set of parameters.

Dissimilarity matrices were calculated (omitting one plot that contained no exotic species) based on the nearest neighbour Sørenson dissimilarity index $\left(\beta_{\text {sor }}\right.$; Eq. 1), its turnover component, the Simpson index of dissimilarity $\left(\beta_{\text {sim }}\right)$, as well as its nestedness component $\left(\beta_{\text {sne }}\right)$-a special case of richness difference.

$$
\begin{aligned}
\beta_{\text {sor }} & =\beta_{\text {sim }}+\beta_{\text {sne }} \equiv \frac{b+c}{2 a+b+c} \\
& =\frac{b}{b+a}+\frac{c-b}{a+b+c} \frac{a}{2 b+a} .
\end{aligned}
$$

Here $a$ is the number of shared species between two neighbouring sites, $b$ the number of species unique to the poorest site and $c$ the number of species unique to the richest site (Baselga and Orme 2012).

All analyses were carried out in $\mathrm{R}$ version 4.0.2 ( $\mathrm{R}$ Core Team 2020), using packages BETAPART v 1.5.1 (Baselga et al. 2020) and vEGAN v 2.5-6 (Oksanen et al. 2020).

\section{Results}

Of the 413 plant taxa that were observed in total, 286 were identified to species level. Some 52 species were exotic and one species (Cyperus esculentus) was of uncertain origin. The number of exotic species per plot ranged from 0 (2625 m a.s.l.) to 17 (1875 and $1975 \mathrm{~m}$ a.s.1.) with an average of 8.7 ( \pm 1.5 s.e.). The average number of indigenous species was 39 ( \pm 3.2 s.e.) species per plot. Most of the sites had wetland properties, whereas dryer conditions occurred more frequently at high elevations. The 11 highest sites had LPq type soils, some 7 sites were of the RGe type and only the lowest site had RGd type soils. Indigenous 
species richness followed a unimodal (hump-shaped) distribution along the elevational gradient, while exotic species richness showed a strong linear correlation. Temperature showed a linear correlation as well (Fig. 2; Table 1). For both indigenous and exotic species, abundance data were strongly correlated with species richness (Table 1).

The final distance-based redundancy analysis model (Fig. 3) using the mean temperature of the coldest day of each year $\left(T_{\min }\right)$ and soil properties was significant with $p<0.001$ and the first two axis, dbRDA1 and dbRDA2, both achieved $p$-values of 0.001 . This model constrained about $27 \%$ of the square-root transformed Bray distance ( $R^{2}$ adjusted), $14.5 \%$ of which through dbRDA1 and $8.3 \%$ through dbRDA2. The lower elevation sites were crowding around the centroids of the Regosol soil types (Fig. 3). In contrast, the higher elevation sites formed two clusters, with the three highest plots somewhat separated from the others in the lower right corner. The three highest plots had relatively low $T_{\min }$ values. Overall, there was a strong association of the exotic species community composition with soil type. At higher elevations, the colder climate (especially low

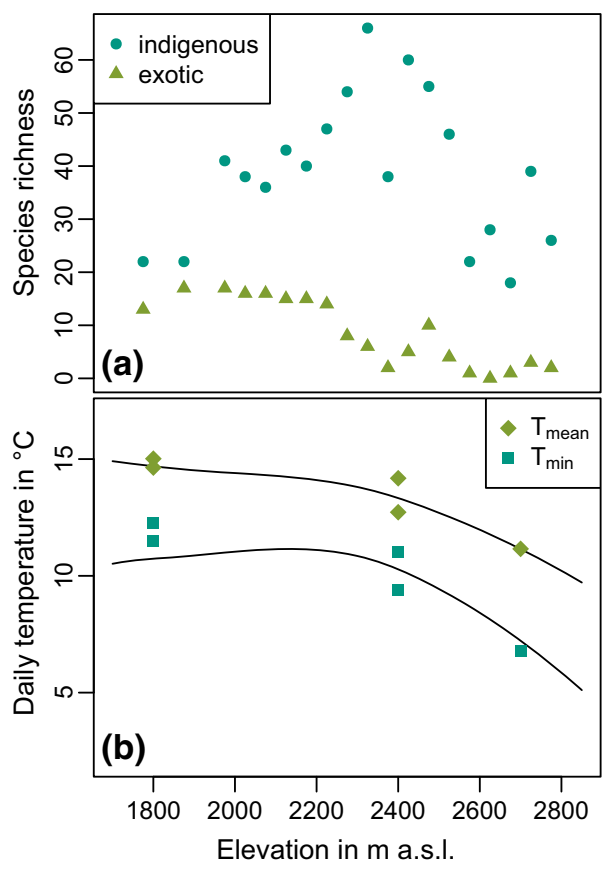

Fig. 2 a Scatterplot of indigenous and exotic species richness against elevation, and $\mathbf{b}$ polynomial regression models for mean and minimum annual temperature against elevation (see also Appendix S1) daily mean temperatures during the cold season) further explained exotic species composition (Fig. 3).

Below approximately $2250 \mathrm{~m}$ a.s.1., which was also roughly the border between the two main soil types, total $\beta$-diversity arose almost exclusively from species turnover (Fig. 4). Following a slight decrease at medium elevations, the pattern became rather irregular and nestedness started to contribute considerably to the total dissimilarity between neighbouring plots.

The relationship between indigenous and exotic species richness differed fundamentally among soil types (Fig. 5). An $\alpha$-level of 0.1 was chosen to account for the relatively low sample size. While RGe/TMtype plots showed a strong decrease of exotic species richness with increasing indigenous species $(p=0.07)$, the correlation was positive for LPq/TEtype plots $(p<0.05$; Table 2$)$. Temperature indices showed moderate correlations with exotic species richness for plots within the $\mathrm{LPq}$ soil type area whereas these relationships were weak and insignificant for the lower RGe soil type plots. Elevation was always negatively correlated to exotic richness.

\section{Discussion}

The negative correlation between indigenous and exotic species richness at RGe-type plots suggests that the biotic resistance hypothesis applies here. These plots had thicker soils and were found at low elevations, where winter temperatures were milder. Competition is likely the main limitation to the spread of exotic plants under these conditions. At LPq-type plots, on the other hand, we found a positive relationship, suggesting that the biotic acceptance hypothesis applies at those sites. Both indigenous and exotic species are affected by the colder winters and thin, instable soils. Here, exotic species may profit from resident plant diversity through facilitation. The possible underlying ecological mechanisms and alternative explanations are discussed in detail below.

Most exotic species occurred at RGe-type plots, where temperatures were milder and soils were better developed. This observation is common in studies along elevational gradients (Alexander et al. 2011; Barni et al. 2012), yet few studies on exotic species in montane ecosystems have considered the effect of soil properties on indigenous and exotic plant community compositions. The negative correlation between 
Table 1 Pearson correlations between biotic and abiotic variables

\begin{tabular}{|c|c|c|c|c|c|c|c|}
\hline & \multicolumn{2}{|c|}{ Indigenous species } & \multicolumn{2}{|c|}{ Exotic species } & \multirow[t]{2}{*}{ Elevation } & \multicolumn{2}{|c|}{ Temperature } \\
\hline & Richness & Abundance & Richness & Abundance & & $T_{\min }$ & $T_{\text {mean }}$ \\
\hline Indigenous species richness & & $0.75 * *$ & 0.10 & 0.01 & 0.00 & 0.39 & 0.24 \\
\hline Indigenous species abundance & & & $0.54 *$ & 0.31 & $-0.52 *$ & $0.78 * *$ & $0.70 * *$ \\
\hline Exotic species richness & & & & $0.80 * *$ & $-0.88 * *$ & $0.77 * *$ & $0.83 * *$ \\
\hline Exotic species abundance & & & & & $-0.65 * *$ & $0.56^{*}$ & $0.61 * *$ \\
\hline Elevation & & & & & & $-0.85 * *$ & $-0.94 * *$ \\
\hline$T_{\min }$ & & & & & & & $0.98 * *$ \\
\hline
\end{tabular}

Indigenous species richness showed a unimodal distribution along the elevational gradient

$*_{p}<0.05, * * p<0.01$

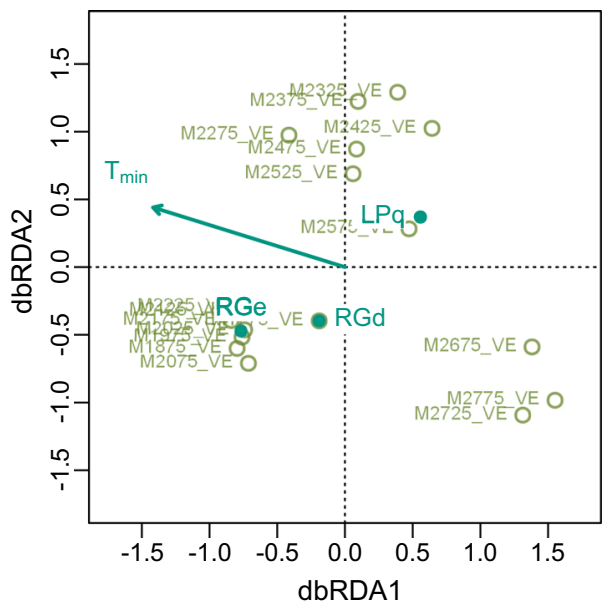

Fig. 3 Distance-based redundancy analysis for the exotic species communities. The arrow depicts the mean temperature of the coldest day of the year $\left(T_{\min }\right)$. Points indicate centroids of the three soil types RGe [eutric Regosols; weakly developed mineral soils, high base saturation (BS)], RGd (dystric Regosols; low BS) and LPq (lithic Leptosols; barely developed soils)

indigenous and exotic species richness on those soils is consistent with other studies carried out in absence of significant abiotic stress (Kennedy et al. 2002; Naeem et al. 2000; Tilman 1997). This pattern supports the idea that biotic resistance through competition is a significant underlying ecological mechanism under favourable abiotic conditions. Studies on plant-plant interactions confirm this competitive effect of neighbouring plants on the performance of target plants at low elevations (Callaway et al. 2002; Choler et al. 2001). A species-rich resident community with abundant strong competitors limits the success of intruders

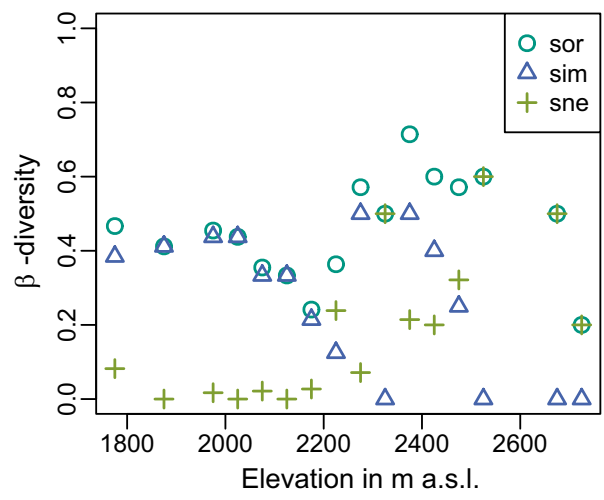

Fig. $4 \beta$-Diversity of exotic species between neighbouring sites along the height gradient; $\mathrm{x}$-axis indicates elevation of the lower neighbour. Symbols display Sørensen index of dissimilarity (sor) green circles, Simpson index of dissimilarity (sim) blue triangles, i.e., the turnover component of Sørensen dissimilarity, and the nestedness component of Sørensen dissimilarity (sne) green plus

(Case 1990). Such competitive exclusion explains the negative correlation between indigenous and exotic species richness observed in the RGe plots. Hence, the biotic resistance hypothesis describes the pattern of indigenous and exotic species in the lower elevational range, where relatively favourable abiotic conditions prevail.

At the high elevation LPq-type plots, both indigenous and exotic species showed a negative correlation with increasing elevation (Table 2b), indicating that both species groups are affected by harsh abiotic conditions. Only few exotic species extended their ranges to high elevations, which can be explained by species-specific climatic limitations (Barni et al. 2012; 


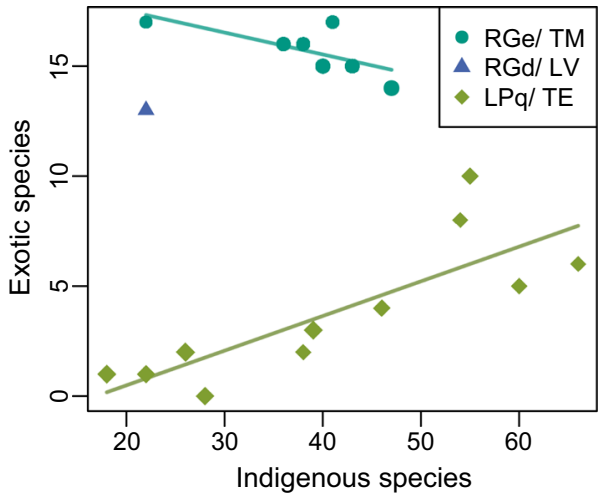

Fig. 5 Exotic species richness plotted against indigenous species richness. The symbols indicate site properties: RGe/ $\mathrm{TM}$ are eutric Regosols on high gradient mountains, $\mathrm{RGd} / \mathrm{LV}$ are dystric Regosols at the valley floor and LPq/TE are lithic Leptosols on high gradient escarpment zones

Table 2 Pearson correlation coefficients between biotic and abiotic variables and exotic species richness under different soil environments: (a) $\mathrm{RGe}=$ Eutric Regosols and (b) $\mathrm{LPq}=$ Lithic Leptosols

\begin{tabular}{lrr}
\hline Variable & Estimate & $p$-value \\
\hline (a) RGe soil type (all df-values = 5) & & \\
$\quad$ Elevation & -0.95 & 0.001 \\
$T_{\text {min }}$ & -0.65 & 0.109 \\
$T_{\text {mean }}$ & 0.96 & 0.001 \\
Indigenous species richness & -0.71 & 0.073 \\
(b) LPq soil type (all df-values =9) & & \\
Elevation & -0.61 & 0.046 \\
$T_{\text {min }}$ & 0.59 & 0.056 \\
$T_{\text {mean }}$ & 0.59 & 0.054 \\
Indigenous species richness & 0.82 & $<0.001$ \\
\hline
\end{tabular}

Pauchard et al. 2009). Since exotic species invading the study area are mostly generalists (Steyn et al. 2017), many are not particularly well adapted to extreme temperatures (Kühn et al. 2020). Poorly developed soils on steep slopes can be expected to cause additional stress through their instability and low water holding capacity. The positive correlation between indigenous and exotic species richness indicates that plant-plant interactions had no overall negative effect on exotic plants at high elevations. This finding is in concordance with the proposed prevalence of facilitating interactions in such environments (Callaway et al. 2002; Choler et al. 2001). Soil instability causes a lower vegetation density, which reduces competitive pressure (Bonan 1993). Furthermore, abiotic stress promotes a flora of rather specialized species (Thuiller et al. 2004). The persistence of such species relies on the inability of competitors to thrive in a harsh environment. Several authors proposed a facilitating effect of resident species richness on the establishment of potential exotic invaders by ameliorating severe stresses (Hacker and Gaines 1997; Simberloff and Von Holle 1999). Therefore, the combination of poorly developed soils and cold winter temperatures is the main restriction for the spread of exotic species to those elevations. Under these conditions, the relationship between indigenous and exotic species richness is described by the biotic acceptance hypothesis.

Elevation itself was not discussed in detail, since it is only a proxy for a complex interplay of other geophysical drivers that may directly or indirectly affect exotic species richness, e.g., through their impact on indigenous species distribution. One cannot assume that such drivers follow a strict linear relationship with elevation (Körner 2007). The dbRDA model did not improve by adding more than two explanatory variables ( $T_{\min }$ and soil type). This was due to the collinearity among variables (Table 1 ). For example, landform and soil information were perfectly linked: one type of soil is associated with one landform. Such a correlation is expected, due to a strong effect of landform and lithology on potential soil development and erosion (Jenny 1941).

Our results are in line with global analyses on indigenous/exotic elevation relationships whereby a unimodal pattern for indigenous species richness is ascribed to the mid-domain affect, while exotic species richness showed a linear relationship with climate (Haider et al. 2018). Such linear relationship between exotics and elevation is generally explained by climate, propagule pressure and residence time, and directional ecological filtering (Alexander et al. 2011; Steyn et al. 2017). Our results suggest that competitive restrictions to exotic species richness predominate at low elevation sites. Such competitive restrictions may then act as a directional ecological filter for the spread of lowland-introduced exotics to higher elevations, but do not mitigate jump-dispersal from the lowland species pool to potential points of introduction at high elevation.

A main limitation of data on exotic species in montane ecosystems is that exotic populations are at 
the periphery of their distribution range. Not all exotic species have yet reached the limit of their potential distribution range yet. Hence, the relationship between indigenous and exotic species is likely to change over time (Kalwij et al. 2015; le Roux and McGeoch 2008). There is also some uncertainty whether a sampled species is truly established at the sampling location or a randomly occurring short-lived single individual (Rocchini et al. 2011). However, most exotic species were shown to persist or continue to increase their upper elevational limit (Kalwij et al. 2015). While exotic species are well known, annually monitored, and identifiable (Kalwij et al. 2008, 2015), a large number of indigenous species could not be identified as a consequence of their flowering period. However, the assessment of $\alpha$-diversity merely requires the distinction between species (Peet 1974). Therefore, the number of unidentified indigenous species does not affect the results. While our study is a strong indication that plant-plant interaction may shift from competition under favourable conditions to facilitation under stress (Callaway et al. 2002), we did not observe such interactions directly. An in situ experiment could be conducted to provide additional evidence to confirm or reject this hypothesis. Finally, recent work suggests that the discussed mechanisms are not restricted to road verges, but also apply at the undisturbed hinterland (Turner et al., unpublished manuscript). This may pose a threat to extraordinarily diverse natural communities in montane areas, such as the flora of the Drakensberg, and needs to be explored in further detail.

\section{Conclusions}

Ecological drivers of exotic plant populations vary along an environmental gradient. Under low or moderate abiotic stress at relatively low elevation, the relationship between indigenous and exotic species fits the biotic resistance hypothesis. Here, species richness may lower the susceptibility of resident communities to plant invasions. Under harsher conditions, indigenous species are more likely to facilitate exotics than to be competitors. Consequently, exotic species that tolerate the abiotic conditions at high elevation are likely to encounter little resistance from the resident communities. The main restriction preventing the spread of exotics to high elevations are poorly developed soils and cold winter temperatures. A change in climatic conditions, nutrient availability or disturbance regimes could deactivate these abiotic barriers, triggering invasions and loss of biodiversity (Didham et al. 2007).

Acknowledgements This project was supported by the DSINRF Centre of Excellence for Invasion Biology, and the University of Johannesburg. We are indebted to Sophia Turner, Lisa Schwarz, Jonas Rotert and Suzaan Kritzinger for field assistance, and to Tom R. Bishop for logistic support and final comments on the manuscript.

Funding Open Access funding enabled and organized by Projekt DEAL.

\section{Compliance with ethical standards}

Conflict of interest The authors declare that they have no conflict of interest.

Open Access This article is licensed under a Creative Commons Attribution 4.0 International License, which permits use, sharing, adaptation, distribution and reproduction in any medium or format, as long as you give appropriate credit to the original author(s) and the source, provide a link to the Creative Commons licence, and indicate if changes were made. The images or other third party material in this article are included in the article's Creative Commons licence, unless indicated otherwise in a credit line to the material. If material is not included in the article's Creative Commons licence and your intended use is not permitted by statutory regulation or exceeds the permitted use, you will need to obtain permission directly from the copyright holder. To view a copy of this licence, visit http://creativecommons.org/licenses/by/4.0/.

\section{References}

Ackerman JD, Tremblay RL, Rojas-Sandoval J, HernándezFigueroa E (2017) Biotic resistance in the tropics: patterns of seed plant invasions within an island. Biol Invasions 19:315-328. https://doi.org/10.1007/s10530-016-1281-4

Alexander JM, Kueffer C, Daehler CC, Edwards PJ, Pauchard A, Seipel T, MIREN Consortium (2011) Assembly of nonnative floras along elevational gradients explained by directional ecological filtering. Proc Natl Acad Sci USA 108:656-661. https://doi.org/10.1073/pnas.1013136108

Alexander JM, Lembrechts JJ, Cavieres LA, Daehler C, Haider S, Kueffer C, Liu G, McDougall K, Milbau A, Pauchard A, Rew LJ, Seipel T (2016) Plant invasions into mountains and alpine ecosystems: current status and future challenges. Alp Bot 126:89-103. https://doi.org/10.1007/ s00035-016-0172-8

Alexander JM, Naylor B, Poll M, Edwards PJ, Dietz H (2009) Plant invasions along mountain roads: the altitudinal amplitude of alien Asteraceae forbs in their native and 
introduced ranges. Ecography 32:334-344. https://doi.org/ 10.1111/j.1600-0587.2008.05605.x

Alpert P, Bone E, Holzapfel C (2000) Invasiveness, invasibility and the role of environmental stress in the spread of nonnative plants. Perspect Plant Ecol Evol Syst 3:52-66. https://doi.org/10.1078/1433-8319-00004

Barni E, Bacaro G, Falzoi S, Spanna F, Siniscalco C (2012) Establishing climatic constraints shaping the distribution of alien plant species along the elevation gradient in the Alps. Plant Ecol 213:757-767. https://doi.org/10.1007/ s11258-012-0039-z

Barthlott W, Hostert A, Kier G, Küper W, Kreft H, Mutke J, Rafiqpoor MD, Sommer JH (2007) Geographic patterns of vascular plant diversity at continental to global scales. Erdkunde 61:305-315. https://doi.org/10.3112/erdkunde. 2007.04.01

Baselga A, Orme CDL (2012) Betapart: an R package for the study of beta diversity. Methods Ecol Evol 3:808-812. https://doi.org/10.1111/j.2041-210X.2012.00224.X

Baselga A, Orme D, Villeger S, Bortoli JD, Leprieur F, Logez M, Henriques-Silva R (2020) Betapart: partitioning beta diversity into turnover and nestedness components. http:// cran.r-project.org/web/packages/betapart. Accessed 22 Sept 2020

Bishop TR, Robertson MP, van Rensburg BJ, Parr CL (2014) Elevation-diversity patterns through space and time: ant communities of the Maloti-Drakensberg Mountains of southern Africa. J Biogeogr 41:2256-2268. https://doi.org/ 10.1111/jbi.12368

Blanchet FG, Legendre P, Borcard D (2008) Forward selection of explanatory variables. Ecology 89:2623-2632. https:// doi.org/10.1890/07-0986.1

Bonan GB (1993) Analysis of neighborhood competition among annual plants: implications of a plant growth model. Ecol Model 65:123-136. https://doi.org/10.1016/03043800(93)90129-G

Bowman WD, Damm M (2002) Causes and consequences of alpine vascular plant diversity in the Rocky Mountains. In: Körner C, Spehn EM (eds) Mountain biodiversity: a global assessment. Routledge, London, pp 35-48

Callaway RM, Brooker RW, Choler P, Kikvidze Z, Lortie CJ, Michalet R, Paolini L, Pugnaire FI, Newingham B, Aschehoug ET, Armas C, Kikodze D, Cook BJ (2002) Positive interactions among alpine plants increase with stress. Nature 417:844-848. https://doi.org/10.1038/ nature 00812

Carbutt C (2012) The emerging invasive alien plants of the Drakensberg Alpine Centre, southern Africa. Bothalia 42:71-85. https://doi.org/10.4102/abc.v42i2.10

Carbutt C (2019) The Drakensberg Mountain Centre: a necessary revision of southern Africa's high-elevation centre of plant endemism. S Afr J Bot 124:508-529. https://doi.org/ 10.1016/j.sajb.2019.05.032

Case TJ (1990) Invasion resistance arises in strongly interacting species-rich model competition communities. Proc Natl Acad Sci USA 87:9610-9614. https://doi.org/10.1073/ pnas.87.24.9610

Chao A, Chazdon RL, Colwell RK, Shen T-J (2005) A new statistical approach for assessing similarity of species composition with incidence and abundance data. Ecol Lett
8:148-159. https://doi.org/10.1111/j.1461-0248.2004. 00707.x

Choler P, Michalet R, Callaway RM (2001) Facilitation and competition on gradients in alpine plant communities. Ecology 82:3295-3308. https://doi.org/10.1890/00129658(2001)082[3295:FACOGI]2.0.CO;2

Didham RK, Tylianakis JM, Gemmell NJ, Rand TA, Ewers RM (2007) Interactive effects of habitat modification and species invasion on native species decline. Trends Ecol Evol 22:489-496. https://doi.org/10.1016/j.tree.2007.07.001

Elton CS (1958) The ecology of invasions by animals and plants. Springer, New York . https://doi.org/10.1007/978-1-48997214-9

Feng Y, Fouqueray TD, van Kleunen M (2019) Linking Darwin's naturalisation hypothesis and Elton's diversity-invasibility hypothesis in experimental grassland communities. J Ecol 107:794-805. https://doi.org/10.1111/ $1365-2745.13061$

Ferreira C (2003-2015) Long-term research: Sani Pass transect. DSI-NRF Centre of Excellence for Invasion Biology, Stellenbosch. https://ir.sun.ac.za/cib/handle/123456789/ 397

Fridley JD, Stachowicz JJ, Naeem S, Sax DF, Seabloom EW, Smith MD, Stohlgren TJ, Tilman D, Von Holle B (2007) The invasion paradox: reconciling pattern and process in species invasions. Ecology 88:3-17. https://doi.org/10. 1890/0012-9658(2007)88[3:tiprpa]2.0.co;2

Hacker SD, Gaines SD (1997) Some implications of direct positive interactions for community species diversity. Ecology 78:1990-2003. https://doi.org/10.1890/00129658(1997)078[1990:SIODPI]2.0.CO;2

Haider S, Kueffer C, Bruelheide H, Seipel T, Alexander JM, Rew LJ, Arévalo JR, Cavieres LA, McDougall KL, Milbau A, Naylor BJ, Speziale K, Pauchard A (2018) Mountain roads and non-native species modify elevational patterns of plant diversity. Glob Ecol Biogeogr 27:667-678. https:// doi.org/10.1111/geb.12727

Hazelton P, Murphy B (2016) Interpreting soil test results: what do all the numbers mean?, 3rd edn. CSIRO Publishing, Collingwood

ISRIC (2013) SOTER Data Model v.10. ISRIC-World Soil Information, Wageningen. https://doi.org/https://doi.org/ 10.17027/isric-wdesoils.20180002

IUSS Working Group WRB (2015) World Reference Base for Soil Resources 2014, update 2015. International soil classification system for naming soils and creating legends for soil maps. World Soil Resources Reports No. 106. FAO, Rome

Jenny H (1941) Factors of soil formation: a system of quantitative pedology. McGraw-Hill, New York

Kalwij JM, Robertson MP, Van Rensburg BJ (2008) Human activity facilitates altitudinal expansion of exotic plants along a road in montane grassland, South Africa. Appl Veg Sci 11:491-498. https://doi.org/10.3170/2008-7-18555

Kalwij JM, Robertson MP, van Rensburg BJ (2015) Annual monitoring reveals rapid upward movement of exotic plants in a montane ecosystem. Biol Invasions 17:3517-3529. https://doi.org/10.1007/s10530-015-09753

Kennedy TA, Naeem S, Howe KM, Knops JMH, Tilman D, Reich P (2002) Biodiversity as a barrier to ecological 
invasion. Nature 417:636-638. https://doi.org/10.1038/ nature 00776

Körner C (2003) Alpine plant life, 2nd edn. Springer, Berlin

Körner C (2007) The use of 'altitude' in ecological research. Trends Ecol Evol 22:569-574. https://doi.org/10.1016/j. tree.2007.09.006

Kueffer C, Daehler C, Dietz H, McDougall K, Parks C, Pauchard A, Rew L (2014) The Mountain Invasion Research Network (MIREN). Linking local and global scales for addressing an ecological consequence of global change. GAIA 23:263-265. https://doi.org/10.14512/gaia.23.3.11

Kühn P, Ratier Backes A, Römermann C, Bruelheide H, Haider $S$ (2020) Contrasting patterns of intraspecific trait variability in native and non-native plant species along an elevational gradient on Tenerife, Canary Islands. Ann Bot. https://doi.org/10.1093/aob/mcaa067

le Roux PC, McGeoch MA (2008) Rapid range expansion and community reorganization in response to warming. Glob Change Biol 14:2950-2962. https://doi.org/10.1111/j. 1365-2486.2008.01687.x

Legendre P, Gallagher ED (2001) Ecologically meaningful transformations for ordination of species data. Oecologia 129:271-280. https://doi.org/10.1007/s004420100716

Levine JM, Adler PB, Yelenik SG (2004) A meta-analysis of biotic resistance to exotic plant invasions. Ecol Lett 7:975-989. https://doi.org/10.1111/j.1461-0248.2004. 00657.x

Levine JM, D'Antonio CM (1999) Elton revisited: a review of evidence linking diversity and invasibility. Oikos 87:15-26. https://doi.org/10.2307/3546992

Liedtke R, Barros A, Essl F, Lembrechts JJ, Wedegärtner REM, Pauchard A, Dullinger S (2020) Hiking trails as conduits for the spread of non-native species in mountain areas. Biol Invasions 22:1121-1134. https://doi.org/10.1007/s10530019-02165-9

Lockwood JL, Cassey P, Blackburn T (2005) The role of propagule pressure in explaining species invasions. Trends Ecol Evol 20:223-228. https://doi.org/10.1016/j.tree.2005. 02.004

MacArthur R (1970) Species packing and competitive equilibrium for many species. Theor Popul Biol 1:1-11. https:// doi.org/10.1016/0040-5809(70)90039-0

McArdle BH, Anderson MJ (2001) Fitting multivariate models to community data: a comment on distance-based redundancy analysis. Ecology 82:290-297. https://doi.org/10. 1890/0012-9658(2001)082[0290:FMMTCD]2.0.CO;2

McDougall KL, Lembrechts J, Rew LJ, Haider S, Cavieres LA, Kueffer C, Milbau A, Naylor BJ, Nuñez MA, Pauchard A, Seipel T, Speziale KL, Wright GT, Alexander JM (2018) Running off the road: roadside non-native plants invading mountain vegetation. Biol Invasions 20:3461-3473. https://doi.org/10.1007/s10530-018-1787-z

McKinney ML (2002) Influence of settlement time, human population, park shape and age, visitation and roads on the number of alien plant species in protected areas in the USA. Divers Distrib 8:311-318. https://doi.org/10.1046/j.14724642.2002.00153.x

Mucina L, Rutherford MC (2006) The vegetation of South Africa, Lesotho and Swaziland. South African National Biodiversity Institute, Pretoria
Naeem S, Knops JMH, Tilman D, Howe KM, Kennedy T, Gale S (2000) Plant diversity increases resistance to invasion in the absence of covarying extrinsic factors. Oikos 91:97-108. https://doi.org/10.1034/j.1600-0706.2000. 910108.x

Nel W, Sumner P (2008) Rainfall and temperature attributes on the Lesotho-Drakensberg escarpment edge, southern Africa. Geogr Ann A 90:97-108. https://doi.org/10.1111/j. 1468-0459.2008.00337.x

Oksanen J, Blanchet FG, Friendly M, Kindt R, Legendre P, McGlinn D, Minchin PR, O'Hara RB, Simpson GL, Solymos P, Stevens MHH, Szoecs E, Wagner H (2020) vegan: Community Ecology Package. https://cran.rproject.org/web/packages/vegan/. Accessed 22 Sept 2020

Palmer MW, Maurer TA (1997) Does diversity beget diversity? A case study of crops and weeds. J Veg Sci 8:235-240. https://doi.org/10.2307/3237352

Pauchard A, Kueffer C, Dietz H, Daehler CC, Alexander J, Edwards PJ, Arévalo JR, Cavieres LA, Guisan A, Haider S, Jakobs G, McDougall K, Millar CI, Naylor BJ, Parks CG, Rew LJ, Seipel T (2009) Ain't no mountain high enough: plant invasions reaching new elevations. Front Ecol Environ 7:479-486. https://doi.org/10.1890/080072

Peet RK (1974) The measurement of species diversity. Annu Rev Ecol Syst 5:285-307. https://doi.org/10.1146/annurev. es.05.110174.001441

Petchey OL, Gaston KJ (2002) Functional diversity (FD), species richness and community composition. Ecol Lett 5:402-411. https://doi.org/10.1046/j.1461-0248.2002. 00339.x

Petitpierre B, McDougall K, Seipel T, Broennimann O, Guisan A, Kueffer C (2016) Will climate change increase the risk of plant invasions into mountains? Ecol Appl 26:530-544. https://doi.org/10.1890/14-1871

R Core Team (2020) R: a language and environment for statistical computing. R Foundation for Statistical Computing, Vienna

Rahbek C, Borregaard MK, Colwell RK, Dalsgaard B, Holt BG, Morueta-Holme N, Nogues-Bravo D, Whittaker RJ, Fjeldså J (2019) Humboldt's enigma: what causes global patterns of mountain biodiversity? Science 365:1108. https://doi.org/10.1126/science.aax0149

Richardson DM, Pyšek P, Rejmánek M, Barbour MG, Panetta FD, West CJ (2000) Naturalization and invasion of alien plants: concepts and definitions. Divers Distrib 6:93-107. https://doi.org/10.1046/j.1472-4642.2000.00083.x

Rocchini D, Hortal J, Lengyel S, Lobo JM, Jiménez-Valverde A, Ricotta C, Bacaro G, Chiarucci A (2011) Accounting for uncertainty when mapping species distributions: the need for maps of ignorance. Prog Phys Geogr 35:211-226. https://doi.org/10.1177/0309133311399491

Seipel T, Kueffer C, Rew LJ, Daehler CC, Pauchard A, Naylor BJ, Alexander JM, Edwards PJ, Parks CG, Arevalo JR, Cavieres LA, Dietz H, Jakobs G, McDougall K, Otto R, Walsh N (2012) Processes at multiple scales affect richness and similarity of non-native plant species in mountains around the world. Glob Ecol Biogeogr 21:236-246. https:// doi.org/10.1111/j.1466-8238.2011.00664.x

Shea K, Chesson P (2002) Community ecology theory as a framework for biological invasions. Trends Ecol Evol 
17:170-176.

5347(02)02495-3

https://doi.org/10.1016/S0169-

Simberloff D, Von Holle B (1999) Positive interactions of nonindigenous species: invasional meltdown? Biol Invasions 1:21-32. https://doi.org/10.1023/A:1010086329619

Steyn C, Greve M, Robertson MP, Kalwij JM, le Roux PC (2017) Alien plant species that invade high elevations are generalists: support for the directional ecological filtering hypothesis. J Veg Sci 28:337-346. https://doi.org/10.1111/ jvs. 12477

Stohlgren TJ, Barnett DT, Kartesz JT (2003) The rich get richer: patterns of plant invasions in the United States. Front Ecol Environ 1:11-14. https://doi.org/10.1890/15409295(2003)001[0011:TRGRPO]2.0.CO;2

Stohlgren TJ, Binkley D, Chong GW, Kalkhan MA, Schell LD, Bull KA, Otsuki Y, Newman G, Bashkin M, Son Y (1999) Exotic plant species invade hot spots of native plant diversity. Ecol Monogr 69:25-46. https://doi.org/10.1890/ 0012-9615(1999)069[0025:EPSIHS]2.0.CO;2

Stohlgren TJ, Jarnevich C, Chong GW, Evangelista PH (2006) Scale and plant invasions: a theory of biotic acceptance. Preslia 78:405-426

Thuiller W, Lavorel S, Midgley G, Lavergne S, Rebelo T (2004) Relating plant traits and species distributions along bioclimatic gradients for 88 Leucadendron taxa. Ecology 85:1688-1699. https://doi.org/10.1890/03-0148

Tilman D (1997) Community invasibility, recruitment limitation, and grassland biodiversity. Ecology 78:81-92. https:// doi.org/10.1890/0012-9658(1997)078[0081:CIRLAG]2.0. $\mathrm{CO} ; 2$

Publisher's Note Springer Nature remains neutral with regard to jurisdictional claims in published maps and institutional affiliations. 